\title{
The Effect of Everyone is a Teacher Here Model and Self-Regulated Learning Towards Learning Outcomes of Indonesian History
}

\author{
R.A. Pratama ${ }^{1}$, N. Ibrahim ${ }^{2}$, Sarkadi ${ }^{3}$ \\ 1,2,3 History Education Department, Postgraduate, Jakarta State University, \\ Jakarta, Indonesia \\ e-mail: rinaldoadi@outlook.com¹, sarkadi09@yahoo.co.id², nurzengky.ibrahim@yahoo.co.id³
}

\begin{abstract}
This research aimed at finding the influence of the learning model Everyone Is a Teacher Here and Self-Regulated Learning towards Learning Outcomes of Indonesia History. The research was conducted at SMAN 8 Tangerang in the academic year 2017/2018. The research method was an experiment, with treatment by level $2 X 2$. Results show that the students who were treated with the "Everyone Is a Teacher Here model" had excellent learning outcomes, compared to those who were given direct model learning. Besides, groups of students who had great self-regulated learning and received learning "Everyone Is a Teacher Here" had higher learning outcomes in Indonesian history compared to those given direct learning. The other result shows that groups of students who had low Self-Regulated Learning and received direct learning have higher learning outcomes in Indonesian history compared to those studied "Everyone Is a Teacher Here." Ultimately, there was an interaction effect between the learning model and the Self-Regulated Learning of the learning outcomes of Indonesian history.
\end{abstract}

Keywords: Everyone Is a Teacher Here, Self-Regulated Learning, Learning Outcomes

\section{Introduction}

The subject of Indonesian History taught in schools means to achieve the goals of national education. It is mainly related to efforts to foster and develop attitudes, character, and social and national responsibility of students (Hasan, 2012). In order to achieve the objectives as mentioned above, of course, learning Indonesian History must be presented through interesting and fun ways so that students are comfortable in the learning process (Hasan, 2013).

However, in reality, the conditions in real life have not yet fully materialized. Based on preliminary observations made by researchers regarding the learning of Indonesian History at SMAN 8 Tangerang, it shows a lack of active participation of students and has an impact on the final results in learning Indonesian History. Learning carried out by the teacher is still direct and does not indicate the existence of a student-centered approach. It happens because there is an initial perception of the students regarding the subjects of Indonesian History, which are in the form of memorization only. It needs to be told by the teacher.

In the process of learning the History of Indonesia in SMAN 8, Tangerang is still less effective and efficient. In the question and answer process, there were only a few students who asked. The majority were passive in asking due to a lack of motivation in asking. Besides, when allowed to argue, no one expressed their opinion. There was hesitation in conveying ideas, and it can be seen from the attitude of the students who expressed their opinions to their closest friends but did not dare before all students. It is because there is no initiative to argue and provide ideas and ideas.

Besides, when the teacher provides an opportunity to review the material that has been discussed, the students are unable to re-explain the material they obtained using their own words. It reflects the low communication skills of students. If the situation is allowed, it will cause the emergence of habits of students who have no motivation to ask questions, argue, give ideas, and refute, even more so if there is a misunderstanding in understanding and understanding the Indonesian History subject matter being studied. After seeing the results of the tests conducted by the teacher, it was seen that the student learning outcomes 
obtained were still below the Minimum Completion Criteria (KKM) of 75 , which had been set by the school.

In this study, the applied learning strategy is an active learning model strategy learning Everyone Is a Teacher Here in learning Indonesian History. Everyone Is a Teacher Here is a model that is easy to implement to obtain large class participation and individual responsibility (Silberman, 2012). This learning model is a model that emphasizes communication between students and demands maximum learning outcomes (Sirinterlikci, 2009). Planning learning model Everyone Is a Teacher Here is the distribution of cards to each student as a media writing specific questions/themes/topics that will be discussed and explained by students in front of the class.

With these learning steps, students are required to explain the material on the card they are receiving, making it possible to get the participation of students to communicate in learning Indonesian History, because students are required to speak in public, present information, ask questions, and offer objections or argue. With the use of learning models, "Everyone Is a Teacher Here" is expected that students get more learning outcomes than using conventional models or other models considering that SMAN 8 Tangerang is one of the National Referral Schools in Tangerang City.

This model provides an opportunity for each student to act as a teacher towards other students (Michael, 2006). From the challenging theory of learning model "Everyone Is a Teacher Here" stated above can be concluded that what is meant by the learning model Everyone Is a Teacher Here is a model to get participation or increase activity in the learning process (Edwards, 2015). In the learning process, not necessarily all of the teachers, learners just sit quietly and listen to lectures from teachers, but learners can teach one another and share information with other learners. Learning model Everyone is a Teacher Here is an easy model for teachers to gain class participation and individual responsibility.

The purpose of implementing the learning model Everyone Is a Teacher Here is to familiarize students with individual active learning and to cultivate the nature of being brave to ask, not self-conscious, and not afraid of being wrong (Michael, 2006). So this model does require students to be active in making questions and answers so that there is no possibility of sleepy or daydreaming students during the lesson (Ismail, 2009).

The application of the Everyone Is a Teacher Here learning model when combined with students' Self-Regulated Learning is thought to have a significant influence on the learning outcomes of Indonesian History (Rijal, Syamsu \& Suhaedir Bachtiar, 2015; Paulino, P., Isabela Sa \& Adelina Lopes da Silva, 2016). Self-Regulated Learning can be interpreted by being able to accept one's responsibilities, be free in thinking and acting, able to regulate and determine the way of life in fulfilling their wants and needs. In other words, someone is said to have independence if he can be responsible, free to think and act, and can regulate and determine his life according to the wants and needs of the person himself (Hurlock, 2013: 185; Burman, Green CD, \& Shanker, 2015).

Zimmerman has the view that Self-Regulated Learning is a person's self-regulation of his cognitive processes so that learning is successful. The processes of self-regulated learning include; goal setting, planning, self-motivation, attention control, flexible use of learning strategies, self-monitoring, appropriate help-seeking, and selfevaluation (Zimmerman, 1990; Sumantri \& Rachmadtullah. 2016). In other words, SelfRegulated Learning includes processes: goal setting, planning, self-motivation, emotional control, the use of flexible learning strategies, self-monitoring, seeking appropriate help, and self-evaluation.

Zimmerman explained that Self-Regulated Learning means students control their learning activities (Zimmerman, 1990; Agustinawati, 2014). A person can be said to be independent if he can realize the will that is seen from the action and then produce something for him. The Self-Regulated Learning of individuals will continue to develop along with the learning process and environmental conditions to bring up the ability to think and behave.

Self-Regulated Learning in principle relates to learning to investigate, namely in the form of direction and self-control, in order to obtain and use the knowledge they have 
(Schraw, Kent, \& Kendall, 2006; Slavin, 2011). To be able to do this, two things can be done, namely by using a learning program that contains instructions for self-study and involving students to plan and carry out activities. The Self-Regulated Learning of students is a sense of belonging and training in good learning methods. The Self-Regulated Learning of students can, of course, be influenced by themselves and from outside themselves like the environment they face (Basri, 2001).

There are several studies relevant to the learning model "Everyone Is a Teacher Here". The research of Muhammad Amin Said, Nirmayanti, and Nurlina (2015) shows that the application of the learning model Everyone Is a Teacher Here can improve the physics learning outcomes of students of class X a Al Bayan Makassar High School when juxtaposed with direct learning models.

Furthermore, research from Radhiah Arzul, Zulfitri Aima, and Audra Pramitha Muslim (2018) showed that the results of students 'mathematical learning by applying the Everyone Is a Teacher Here strategy was better than students' mathematics learning outcomes by applying conventional learning to class VIII SMP 12 Padang. Research Sulaiman (2016) shows that learning uses the learning strategy Everyone Is a Teacher Here on the subject of the circle has a real influence on student mathematics learning outcomes in SMP Negeri 1 Sukoharjo when compared to conventional strategies. Finally, research from Ina Rohmawati, Eli Rohaeti (2016) showed that there were significant differences in chemistry learning achievement between students who took part in the learning type Everyone is a Teacher Her e active learning strategy when compared to the problem training learning strategies at Cangkringan 1 Public High School.

This research was conducted to see the effect of students' Self-Regulated Learning in the process of learning Indonesian History. With these learning steps, students are required to explain the material on the card they are receiving, making it possible to get the participation of students to communicate in learning Indonesian History, because students are required to speak in public, present information, ask questions, and offer objections or argue. By using the "Everyone Is a Teacher Here" learning model, students are expected to get more learning outcomes compared to using conventional models or other models considering that SMAN 8 Tangerang is one of the National Referral Schools in Tangerang City.

Based on these problems, this study is devoted to looking at the effect of learning models and students' self-regulated learning on the learning outcomes of students in Indonesian History subjects at SMAN 8 Tangerang.

\section{Method}

The method used in this research is to experiment with treatment design by level 2X2. The variables in this study consisted of two independent variables Everyone Is a Teacher Here and Self-Regulated Learning. The dependent variable in this study is the learning outcomes of Indonesian History. This research is an experimental study using one experimental class with the learning model "Everyone Is a Teacher Here" and one control class with a direct learning model.

The infinite population in this study was all $10^{\text {th }}$-grade students consisting of 9 classes as many as 306 affordable students and populations, namely six classes of science majors in 204 students in SMAN 8 Tangerang. Determination of samples in this study was conducted by random sampling technique obtained by two classes, namely class X IPA 3 as the control class and class X IPA 5 as the experimental class. 
Table 1. Design of Experiment with Treatment by Level $2 \times 2$

\begin{tabular}{lcc}
\hline \multirow{2}{*}{ Self-Regulated Learning } & \multicolumn{2}{c}{ Learning Model } \\
\cline { 2 - 3 } & ETH (A1) & Direct Learning (A2) \\
\hline High $\left(B_{1}\right)$ & $A_{1} B_{1}$ & $A_{2} B_{1}$ \\
Low $\left(B_{2}\right)$ & $A_{1} B_{2}$ & $A_{2} B_{2}$ \\
\hline
\end{tabular}

Information:

$A_{1}$ : Groups of students who follow the Everyone Is a Teacher Here

$\mathrm{A}_{2}$ : Groups of students who follow the direct learning

$\mathrm{A}_{1} \mathrm{~B}_{1}$ : The group of students who followed Everyone Is a Teacher Here with high SelfRegulated Learning

$\mathrm{A}_{1} \mathrm{~B}_{2}$ : The group of students who followed Everyone Is a Teacher Here with low SelfRegulated Learning

$A_{2} B_{1}$ : The groups of students who follow the direct learning with high Self-Regulated Learning

$A_{2} B_{2}$ : The groups of students who follow direct learning with low Self-Regulated Learning

Data have been obtained from the data collecting, then performed analysis according to the research objectives of each. Data analysis in this study consisted of two parts, namely, descriptive analysis and differential analysis. Descriptive analysis is done by presenting the distribution table, histogram, average, and standard deviation. Testing the hypothesis is done by using a variance analysis test ANOVA. Before conducting the ANOVA test, the requirements test is carried out in the form of a homogeneity test and normality test.

The normality test to find out the data on student learning outcomes in each group is in the normal distribution. The normality test in this study used the Liliefors Test. Homogeneity test to find out whether Indonesian History learning outcomes data among sample groups are homogeneous. The homogeneity test in this study used the Bartlett Test.

In the final stage of the analysis, if the results show differences and show significant interactions between the independent variables, then the analysis needs to be continued to test which groups are higher using the Tuckey Test.

\section{Result and Discussion}

\subsection{Result}

This research is experimental research with an active learning model, "Everyone is a Teacher Here" as a treatment variable, while the direct learning model as a control variable. The data used as the basis of the description of the results in this research is the students' Self-Regulated Learning and learning outcomes of Indonesian history after treatment. The researcher explained the results research that includes: data description, testing data analysis requirements, hypothesis testing, and discussion.

The results for data on learning outcomes of Indonesian History, including maximum score, minimum score, range, mean, median, mode, variance, and standard deviation. Such data can be presented in the following table below:

Tabel 2. Summary of Learning Outcomes in Indonesian History

\begin{tabular}{lcccccc}
\hline \multicolumn{1}{c}{ DESCRIPTION } & $\mathbf{A}_{\mathbf{1}}$ & $\mathbf{A}_{\mathbf{2}}$ & $\mathbf{A 1 B 1}$ & $\mathbf{A 1 B 2}$ & $\mathbf{A 2 B 1}$ & $\mathbf{A 2 B 2}$ \\
\hline $\mathrm{N}$ & 18 & 18 & 41 & 33 & 32 & 35 \\
MAX & 41 & 35 & 34 & 27 & 26 & 29 \\
MIN & 27 & 26 & 7 & 6 & 6 & 6 \\
RANGE & 14 & 9 & 37,33 & 29,89 & 28,78 & 32,78 \\
MEAN & 33,61 & 30,78 & 41 & 33 & 32 & 35 \\
MEDIAN & 33,50 & 28,83 & 37,00 & 29,50 & 28,75 & 32,83 \\
MODUS & 37,00 & 28,70 & 39,50 & 28,50 & 28,50 & 32,50 \\
VAR & 19,55 & 7,59 & 5,50 & 4,86 & 3,19 & 3,94 \\
ST DEV & 4,42 & 2,76 & 2,35 & 2,20 & 1,79 & 1,99 \\
\hline
\end{tabular}


Hypothesis testing is done after the normality test and homogeneity test. Hypothesis testing is done to test all the main effects and interaction effects on learning outcomes by using two variance analyses $2 \times 2$ two way (ANAVA). The main effect of this research is about the influence of active learning model type Everyone Is a Teacher Here and Self-Regulated Learning of the students towards learning outcomes in Indonesian History SMAN 8 Tangerang. In contrast, the effect of the interaction is about the influence of the interaction between the use of the learning model given to students who have low learning independence.

Then the significance level is carried out by further testing using the Tukey Test. The results of the calculation of path variance analysis with complete statistics will be illustrated in the table below:

Table 3. Calculation of ANOVA Two Way

\begin{tabular}{ccccrrrr}
\hline \multirow{2}{*}{ Source of Variance } & \multirow{2}{*}{ Db } & \multirow{2}{*}{ JK } & \multirow{2}{*}{ RJK } & \multirow{2}{*}{ F $_{\text {count }}$} & \multicolumn{2}{c}{$\mathbf{F}_{\text {table }}$} \\
\cline { 5 - 8 } & & & & & $\mathbf{0 . 0 5}$ & $\mathbf{0 . 0 1}$ \\
\hline Between Columns & 1 & 72.25 & 72.25 & 16,514 & $*$ & 4.20 & 7.77 \\
Interline & 1 & 26.69 & 26.69 & 6,102 & $*$ & 4.20 & 7.77 \\
Interaction & 1 & 294.69 & 294.69 & 67,359 & $* *$ & 4.20 & 7.77 \\
In & 32 & 140.00 & 4.37 & & & & \\
\hline Total Reduced & $\mathbf{3 5}$ & $\mathbf{5 3 3 . 6 4}$ & & & & & \\
\hline
\end{tabular}

$\begin{array}{ll}\text { Information } \\ { }_{*} \quad=\text { Significant } \\ * \star & =\text { Very Significant } \\ \mathrm{Db} & =\text { Degree of Freedom } \\ \mathrm{JK} & =\text { Number of Squares } \\ \mathrm{RK} & =\text { Average of Squares } \\ \mathrm{Fh} & =\mathrm{F} \text { count } \\ \mathrm{F}_{\mathrm{t}} & =\mathrm{F} \text { table }\end{array}$

Based on Table 3 above, hypothesis testing for all effects can be carried out as follows: first hypothesis, the results of ANOVA data $F$ count for learning models with a score of 16.514. In contrast, $F$ table with a score of 4.20 at the actual level $\alpha=0.05$, because $F$ count $>$ $F$ table then $\mathrm{H}_{0}$ rejected and $\mathrm{H}_{1}$ accepted it means that there are differences in learning outcomes Indonesian history between learners use learning models Everyone Here Is a Teacher with students who used direct instructional model. The result showed on this table below:

Table 4. The Result of Learning Outcomes between the student treated by Everyone is a Teacher Here and Direct Learning Model

\begin{tabular}{ccc}
\hline Compared group & \multirow{2}{*}{$\boldsymbol{F}_{\text {count }}$} & $\mathbf{F}$ table \\
\cline { 3 - 3 } & 16,514 & $\boldsymbol{\alpha}=\mathbf{0 , 0 5}$ \\
\hline $\mathrm{A}_{1}$ and $\mathrm{A}_{2}$ & 16,514 & 4,20 \\
\hline
\end{tabular}

Information:

$A_{1}$ : Everyone is a Teacher Here Model

$\mathrm{A}_{2}$ : Direct Learning Model

Based on the table above, It can be seen that there are significant learning outcomes in Indonesian history between learners use the learning model "Everyone Is a Teacher Here" with a direct learning model. Hence, it can be seen from the average value of the learning model Everyone Is a Teacher Here $\left(A_{1}\right)$ with a score of 33.61, while the average value of the direct learning model $\left(A_{2}\right)$ with a score of 30.78 . It can be concluded that the 
results of learning using the learning model Everyone Here Is a Teacher higher than that using the direct learning model.

The second hypothesis, after treatment to the student, there is the influence of the interaction between the use of the learning model and self-regulated learning on the learning outcomes of Indonesian History of students. The result of the calculation showed on this table below:

Table 5. Result of Interaction between Learning Model and Self-Regulated Learning

\begin{tabular}{ccc}
\hline Compared group & $\mathbf{F}_{\text {count }}$ & $\boldsymbol{F}_{\text {table }}$ \\
\cline { 2 - 3 } & & $\mathbf{\alpha = 0 , 0 5}$ \\
\hline $\mathrm{A}_{1} \mathrm{~B}_{1}$ and $\mathrm{A}_{2} \mathrm{~B}_{2}$ & 67,359 & 4,20 \\
\hline
\end{tabular}

Information:

$A_{1} B_{1}$ : The group of students who followed Everyone is a Teacher Here with high SelfRegulated Learning

\section{$A_{2} B_{2}$ : The groups of students who follow direct learning with low Self-Regulated Learning}

The result of ANOVA calculation can be seen that $F_{\text {count }}$ for the interaction factor is 67.359 bigger than the $F_{\text {table }} 4.20$ on the real level $\alpha=0.05$. It shows that there is an interaction effect between the use of learning and self-regulated learning models on student learning outcomes. The data can be concluded that $H_{0}$ is rejected, and $H_{1}$ is accepted. However, the average value of each cell is scored as follows: $A_{1} B_{1}(37.33)$, $A_{1} B_{2}$ (29.89), $A_{2} B_{1}(28.78)$, and $A 2$ B2 (32.78). The hypothesis testing result on the influence of the interaction between the use of learning and self-regulated learning is illustrated as follows.

The third hypothesis, the average of the learning outcomes of students with high selfregulated learning who used "Everyone Is a Teacher Here" $\left(A_{1} B_{1}\right)$ is 37.33 . The average of the students' learning outcomes with high self-regulated learning who used direct learning models $\left(A_{2} B_{1}\right)$ is 28.78 . Both of these values are then compared using the Tukey test

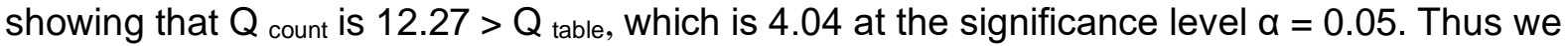
can conclude $\mathrm{H}_{0}$ is rejected, and $\mathrm{H}_{1}$ accepted. It means that for students who have high selfregulated learning, there are differences in learning outcomes with students who use the direct learning model. The result of the Tukey Test showed below:

Table 6. Tukey Test Result For Students' With High Self Regulated Learning Using Everyone Is a Teacher Here And Direct Learning Model

\begin{tabular}{ccc}
\hline Compared Group & $\mathbf{Q}_{\text {count }}$ & $\mathbf{Q}_{\text {table }}$ \\
\cline { 2 - 2 } & 12,27 & $\mathbf{\alpha = 0 , 0 5}$ \\
\hline $\mathrm{A}_{1} \mathrm{~B}_{1}$ dan $\mathrm{A}_{2} \mathrm{~B}_{1}$ & $12,27,04$ \\
\hline
\end{tabular}

Information:

$A_{1} B_{1}$ : Learning outcomes of the student with high self-regulated learning using Everyone Is a Teacher Here learning model

$A_{2} B_{1}$ : Learning outcomes of the student with high self-regulated learning using a direct learning model

Fourth hypothesis, learning outcomes of Indonesian History learners who used Everyone Is a Teacher Here on learners who have low self-regulated learning is lower than the learning outcomes of Indonesian History of the student who used direct learning model. The average value of learning outcomes of Indonesian History of students with low self-regulated learning who used Everyone Is a Teacher Here $\left(A_{1} B_{2}\right)$ that is 29.89 , while the average of learning outcomes in Indonesian History of students with self-regulated learning was low who use the direct learning model $\left(A_{2} B_{2}\right)$ which is 32.78 . 
Tabel 7. Tukey Test Result for Students' with Low Self Regulated Learning Using Everyone Is a Teacher Here and Direct Learning Model

\begin{tabular}{ccc}
\hline Compared Group & \multirow{2}{*}{$\mathbf{Q}_{\text {count }}$} & $\mathbf{Q}_{\text {table }}$ \\
\cline { 3 - 3 } & 4,14 & $\mathbf{\alpha = 0 , 0 5}$ \\
\hline $\mathrm{A}_{1} \mathrm{~B}_{2}$ and $\mathrm{A}_{2} \mathrm{~B}_{2}$ & 4,04 \\
\hline
\end{tabular}

Information:

$A_{1} B_{2}$ : Learning outcomes of the student with low self-regulated learning using Everyone Is a Teacher Here learning model

$A_{2} B_{2}$ Learning outcomes of the student with low self-regulated learning using a direct learning model

The results of these data indicate that $Q$ count that is 4.14 is greater than the $Q$ table, which is 4.04 at the significance level $\alpha=0.05$. It can be concluded that $H_{0}$ is rejected, and $\mathrm{H}_{1}$ accepted, which means that there are differences in learning outcomes of Indonesian History of students who have low self-regulated learning who used Everyone Is a Teacher Here model and students who have low self-regulated learning who use the direct learning model.

\subsection{Discussion}

The results of data analysis are known to be the learning process used Everyone Is a Teacher Here model has a significant and higher effect in optimizing the learning outcomes of Indonesian History of students. Students get better learning outcomes after being given treatment using Everyone Is a Teacher Here model.

Table 8. Tuckey Test Result

\begin{tabular}{cccc}
\hline Compared group & $\mathbf{Q}_{\text {count }}$ & $\mathbf{Q}_{\text {table }}$ & Conclusion \\
\cline { 3 - 3 } & 12.27 & $\boldsymbol{\alpha}=\mathbf{0 . 0 5}$ & \\
\hline $\mathrm{Q}^{2} \mathrm{~A}_{1} \mathrm{~B}_{1}$ and $\mathrm{A}_{2} \mathrm{~B}_{2}$ and $\mathrm{A}_{2} \mathrm{~B}_{2}$ & 4.14 & 4.04 & Reject Ho \\
\hline
\end{tabular}

Based on the table above, it means that Everyone Is a Teacher Here model is a very appropriate model to get class participation as a whole and individually (Zaini, Hisyam, Bermawy Munthe \& Sekar Ayu Aryani, 2008). The students in the experiment class got a great achievement for their learning outcomes. It happens because Everyone Is a Teacher Here model provides an opportunity for each student to act as a teacher for his friends. With this model, students who have been unwilling to be involved will actively participate in learning. According to Silberman, the "Everyone Is a Teacher Here" model is a straightforward model for obtaining substantial class participation and individual responsibility (Silberman, 2009; Freeman et al., 2014).

The results of the first hypothesis testing show that the learning outcomes of students who use the learning model "Everyone Is a Teacher Here" higher than the learning outcomes of Indonesian History of students who use the direct learning model. Students are very active and enthusiastic when the learning process uses a learning model, "Everyone Is a Teacher Here." This model suitable to make students more active and have responsibility for the material obtained so that it is better able to improve the ability of students to communicate about the material being studied (Faust \& Paulson, 1998; Fayombo, 2012).

Thus, students can regulate the rhythm of learning and respect their friends while expressing their opinions in public. They tried to show their skill to communicate with other people and transfer their knowledge to others no matter the material and their explanation mistake or not. This learning model makes the teacher more communicate with the student because of the student not afraid anymore to speak up in the classroom. 
Hypothesis test results for the second hypothesis show that there is an interaction effect between the use of learning models and students' self-regulated learning on the learning outcomes of Indonesian History of students. It proves with the picture below that showed the interaction between both variables:

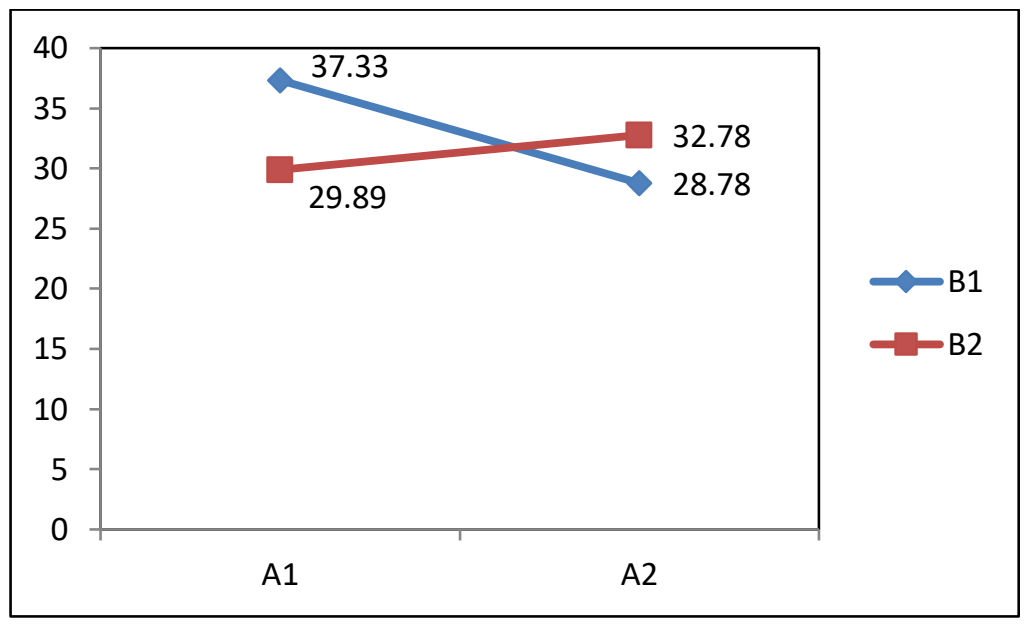

Figure 1. Interactions between variables

Information:

A1: Everyone Is a Teacher Here Model

A2: Direct Learning Model

B1: High Self-Regulated Learning

B2: Low Self-Regulated Learning

The teacher needs to choose the right model to implement in the classroom. The reason for this way because the learning model is one of the essential things in the learning process in the classroom in order to improve and optimize student learning outcomes, whatever the subject learned in, especially in Indonesia History subject because lots of students need to remind past event. Besides, the self-regulated learning possessed by students will be able to increase interest in the learning process of Indonesian History, so the learning outcomes of students in the learning process of Indonesian History will increase.

The results of the third hypothesis test show that the learning outcomes of Indonesian History are students who have great self-regulated learning who use learning models Everyone Is a Teacher Here is higher than students who use the direct learning model. In the learning process, students who have high self-regulated learning will be able to follow the learning model Everyone Is a Teacher Here very well. Students can explain well every theme from the materialization of Islamization and the Sultanates in Indonesia to other students.

"Everyone Is a Teacher Here" learning model is more appropriate to be used by students who have great self-regulated learning. It is because, in the learning process, students are allowed to explain the material in their way until their group mates understand what is explained so that students can express and explain new ideas, and students are happier and more comfortable in completing the learning process.

This model can direct students to have great self-regulated learning in order to understand material. In the learning process learners are required to recognize self-control is within oneself and others, because the teaching model Everyone Here Is a Teacher's Learners are required to explain to the other with a good friend, and another friend who is required to ask, response and refute what has been described. Such learning process will be able to improve learning outcomes of Indonesian History of students, so it can be concluded that the Everyone Is a Teacher Here learning model is useful for students who have high self- 
regulated learning while the direct learning model is used by students who have low selfregulated learning.

The test results in the fourth hypothesis state that the learning outcomes of Indonesian History are students who have low self-regulated learning who use the learning model Everyone Is a Teacher Here lower than the students' learning outcomes of Indonesian History students who have low self-regulated learning who use the direct learning model. It is because, in the learning process, students do not play an active role as students only listen to the material from what is explained by the teacher, so there is no interaction between classmates.

Students who have low self-regulated learning are more appropriate to use the direct learning model because this model is not required for teamwork, each student is not given responsibility in the learning process, so students are not challenged in the learning process. The teacher's direct learning model only explains (lectures) without any exciting activities that require students to play an active role so that this does not require students to have independent learning when the learning process takes place.

The learning process that has been facilitated well by the teacher will be more natural to be followed by students who have low self-regulated learning (Chi \& Ruth Wylie. 2014). Because students are not required to explore their abilities further, and students are not too involved in the learning process. Students are only involved in listening to the explanation from the teacher so that the learning process like this is suitable for students who have low self-regulated learning.

With problems like that, a learning strategy is needed that can encourage the active role of students in learning Indonesian History, which is a strategy that can create conducive learning full of interactions and encourage learning activities that are comfortable and enjoyable (Kochar, 2008; Susanto, 2014; Prince, 2004). Therefore, to improve the learning outcomes of students in Indonesian History, subjects can be done with various strategies and models learning, one of which is using the Everyone Is a Teacher Here active learning model strategy.

\section{Conclusion and Suggestion}

Based Everyone ls a Teacher Here model is a very suitable model to get class participation as a whole and individually in Indonesian History subject. The students in the experiment class got a great achievement for their learning outcomes than the control class, which used a direct learning model. It has happened because "Everyone Is a Teacher Here" model provides an opportunity for each student to act as a teacher for his friends. With this model, students who have been unwilling to be involved will actively participate in learning.

The results of this research showed that Indonesian History learning outcomes in students using the Everyone Is a Teacher Here learning model showed higher results compared to Indonesian History learning outcomes in students who used the direct learning model. There is an influence of interaction between learning and self-regulated learning models towards learning outcomes of Indonesian History.

Learning outcomes of Indonesian History using the Everyone Is a Teacher Here learning model, the students who have high self-regulated learning show higher results compared to the learning outcomes of Indonesian History that use direct learning models in students who have self-regulated learning high. Learning outcomes of Indonesian History using the Everyone Is a Teacher Here learning model students who have low self-regulated learning show lower results than learning outcomes in Indonesian History using direct learning models in students who have low self-regulated learning. It is expected that the next researcher can continue and use this model to improve the learning outcomes of Indonesian History for students.

The teacher can use active learning model type Everyone Is a Teacher Here as an alternative for the learning model during the learning process in the classroom and can optimize the learning outcomes of Indonesian History. Furthermore, the teacher can consider the characteristics of the students, especially in the realm of self-regulated learning, to choose the appropriate learning model in the process of learning. The teacher can provide 
the active learning model type Everyone Is a Teacher Here to students who have high selfregulated learning and a direct learning model to students with low self-regulated learning to improve and optimize learning outcomes for students.

\section{References}

Agustinawati, Nita. 2014. Pengaruh Metode Pembelajaran dan Kemandirian Belajar Terhadap Hasil Belajar Sejarah Siswa di SMAN 7 Cirebon. Jurnal Pendidikan Sejarah. Vol. 3 (2), 1-7.

Arzul, Radhiah., Zulfitri Aima dan Audra Pramitha Muslim. 2018. Pengaruh Penerapan Strategi Everyone Is A Teacher Here (Eth) Terhadap Kemandirian Dan Hasil Belajar Matematika Siswa Kelas VIII SMPN 12 Padang Tahun Pelajaran 2017/2018. Jurnal IImiah Mahasiswa. Diunduh dari: http://jim.stkip-pgrisumbar.ac.id/jurnal/download/1396.

Basri, Hasan. 2001. Psikologi Pendidikan. Jakarta: Dunia Pustaka.

Burman, Jeremy T., Green, C. D., dan Shanker, S. 2015. On the Meanings of SelfRegulation: Digital Humanities in Service of Conceptual Clarity. Child Development. Vol. 86 (5), 1207-1221.

Chi, Michelene T. H. \& Ruth Wylie. 2014. The ICAP Framework: Linking Cognitive Engagement to Active Learning Outcomes. Educational Psychologist, 49 (4), 219-243.

Edwards, Susan. 2015. "Active Learning in the Middle Grades", Middle School Journal, Vol. 46 (5), 26-32.

Faust, J.L., \& Paulson, D.R. 1998. "Active Learning in College Classroom". Journal on Excellence in College Teaching, 9 (2), 3-24.

Fayombo, Grace. 2012. Active Learning Strategies and Student Learning Outcomes Among Some University Students in Barbados. Journal of Educational and Social Research, Special Issue, (2)9, 79-90.

Freeman et.al., .2014. "Active Learning Increases Student Performance in Science, Engineering, And Mathematics," Proceedings of the National Academy of Sciences of the United States of America PNAS, Vol. 111 (23).

Hasan, Said Hamid. 2012. Guru Sejarah Indonesia Isu dalam Ide dan Pembelajaran. Bandung: Rizqi Press.

Hasan, Said Hamid. 2013. History Education in Curriculum 2013: A New Approach to Teaching History. Jurnal HISTORIA: International Journal of History Education. Vol. XIV (2), 163-178.

Hurlock, E. B. 2013. Psikologi Perkembangan. Jakarta: Erlangga.

Ismail. 2009. Strategi Pembelajaran Agama Berbasis PAIKEM. Semarang: Rasail Media Group.

Kochar, S.K. 2008. Pembelajaran Sejarah. Jakarta: Gramedia.

Michael, Joel. 2006 Where's the Evidence That Active Learning Works? Advances in Physiology Education, The American Physiological Society, Vol. 30, 159-167.

Paulino, Paula., Isabela Sa, dan Adelina Lopes da Silva. 2016. Self-Regulation of Motivation: Contributing to Students' Learning in Middle School. The European Proceedings of Social \& Behavioural Science. $4^{\text {th }}$ Annual International Conference on Cognitive - Social, and Behavioural Sciences.

Prince, Michael. 2004. "Does Active Learning Work? A Review of the Research". Journal of Engineering Education. July, 223-231.

Rijal, Syamsu \& Suhaedir Bachtiar. 2015. Hubungan Antara Sikap, Kemandirian Belajar, dan Gaya Belajar dengan Hasil Belajar Kognitif Siswa. Jurnal Bioedukatika, Vol 3(2), 1520.

Rohmawati, Ina dan Eli Rohaeti. 2015. Pengaruh Penerapan Strategi Everyone Is A Teacher Here Terhadap Kemandirian Dan Prestasi Belajar Kimia. Diunduh dari: http://journal.student.uny.ac.id/ojs/index.php/pkimia/article/download/3787/3404.

Said, Muhammad Amin., Nirmayanti, Nurlina. 2015. Penerapan Pembelajaran Aktif Tipe Everyone Is A Teacher Here (ETH) Untuk Meningkatkan Hasil belajar Fisika Peserta 
Didik Kelas XA SMA Al Bayan Makassar. Prosiding Seminar Nasional Fisika (EJournal) Vol. IV, Oktober, 2015.

Schraw, Gregory., Kent J. Crippen, dan Kendall Hartley. 2006. Promoting Self-Regulation in Science Education: Metacognition as Part of a Broader Perspective on Learning. Research in Science Education, Vol. 36, 111-139.

Silberman, Melvin L. 2009. Active Learning: 101 Strategi Pembelajaran Aktif. Yogyakarta: Yappendis.

Sirinterlikci, Arif., Linda Zande dan Aleea L. Sirinterlikci, 2009. "Active Learning Trough Toy Design and Development", The Journal of Technology Studies, Vol. 35(8): 14-22.

Slavin, Robert E. 2011. Psikologi Pendidikan Teori dan Praktik. Jakarta: Indeks.

Sulaiman. 2016. Pengaruh Strategi Everyone Is A Teacher Here Terhadap Hasil Belajar Matematika Siswa. Jurnal E-Dumath. Vol. 2(1), 152-160.

Sumantri, M.S. \& Rachmadtullah, Reza. 2016. The Effect of Learning Media and Self Regulation to Elementary Students' History Learning Outcome. Advanced Science Letters. Vol. 22(12), 4104-4108.

Susanto, Heri. 2014. Seputar Pembelajaran Sejarah (Isu, Gagasan, dan Strategi Pembelajaran). Yogyakarta: Aswaja.

Zaini, Hisyam., Bermawy Munthe, dan Sekar Ayu Aryani. 2008. Strategi Pembelajaran Aktif. Yoyakarta: Pustaka Insan Madani dan CTSD UIN Sunan Kalijaga.

Zimmerman, Barry J. 1990. Self-Regulated Learning and Academic Achievement: An Overview. Educational Psychologist. Vol. 25, 3-17. 